\title{
Genome size and plant development in hexaploid Festuca arundinacea
}

\author{
M. CECCARELLI†, S. MINELLI†, M. FALCINELLI \& \&. G. CIONINI†* \\ $\dagger$ Dipartimento di Biologia Vegetale and $\$$ /stituto di Miglioramento Genetico Vegetale della Università, Borgo XX Giugno \\ 74, 1-06100 Perugia, Italy
}

\begin{abstract}
The development of plants belonging to natural populations of hexaploid Festuca arundinacea with different basic amounts of nuclear DNA was studied. A previous investigation showed that the genome sizes of the populations correlate positively with the mean temperature during the year and with that of the coldest month at the stations. Mitotic cycle time is affected by nuclear DNA content; in a population with a C-value of $6.05 \mathrm{pg}$, it is $3 \mathrm{~h}$ shorter than in a population with a Cvalue of $8.28 \mathrm{pg}$. In contrast, the genome size affects neither the proportion of cells entering mitosis in the meristems, nor the enlargement of cells in differentiated leaf tissues. By studying plant development in 30 populations, it was found that their genome size correlates negatively with the seed germination power $(P=0.036)$ and the early growth of both the seminal root $(P=0.009)$ and the first foliage leaf $(P=0.099)$. By contrast, the genome size correlates positively with the height of the highest culm $(P=0.014)$ and other quantitative characters of the plants at anthesis, as well as with their flowering time $(P=0.037)$. It is suggested that the variations in the basic amount of nuclear DNA within $F$. arundinacea have a role in improving the fitness of plants in environments differing in climatic factors such as temperature.
\end{abstract}

Keywords: evolution within species, Festuca arundinacea, intraspecific DNA changes, nucleotype, plant development.

\section{Introduction}

Highly significant differences in genome size and organization have recently been observed between natural populations of hexaploid Festuca arundinacea Schreber located at stations scattered all along the Italian peninsula. On the basis of the results obtained after morphological, anatomical, karyological and biochemical analyses, however, all the accessions studied should be assumed to belong to one hologamodeme (Cenci et al., 1990). The basic amount of nuclear DNA (C-value) differs by up to 32.3 per cent between populations. In the same way as in other species (cf. Cullis, 1990; Cavallini \& Natali, 1991), these changes are linked to variations in the amount of heterochromatin and in the frequency of repeated DNA sequences, and particularly of a fraction of them (the 'fluid' domains). The genome sizes of the populations are correlated positively with the mean temperature during the year

*Correspondence: Professor P. G. Cionini, Dipartimento di Biologia Vegetale della Università, Borgo XX Giugno 74, I-06100 Perugia, Italy. and with that of the coldest month at the stations, and correlate negatively with their latitudes (Ceccarelli et al., 1992).

These results may be added to several others to be found in the literature to the effect that intraspecific changes in the basic amount of nuclear DNA do occur (reviewed by Bennett, 1985; Cavallini \& Natali, 1991), due to the presence in the genome, possibly more commonly in plants than in animals, of fluid domains. These fractions of nuclear DNA, made up mostly of repeated sequences, are capable of rapid quantitative changes in response to developmental and/or environmental stimuli (reviewed by Cionini, 1989; Bassi, 1990; Cullis, 1990; Nagl, 1990).

Thus far, there is inadequate information about the mechanism(s) by which, in each instance, these DNA quantitative changes are produced and controlled, and, even more, about their biological significance. Concerning their biological significance, there are a few reports indicating (i) whether or not and at what stage(s) intraspecific, quantitative DNA changes actually affect developmental and/or physiological characters of plants, and (ii) the way(s) in which this effect is 
achieved, thus suggesting the underlying adaptive strategies (cf. Natali et al., 1993). Because of our lack of knowledge about these fluxes in DNA amounts, it has even been questioned if intraspecific, quantitative DNA changes always represent programmed responses to variations that environmental or developmental stimuli bring about in the cell activity and microenvironment (Cionini, 1989) or if variations (more or less commonly) simply allow or inhibit the synthesis of DNA sequences to be regarded as selfish DNA (Doolittle \& Sapienza, 1980; Orgel \& Crick, 1980).

In an attempt to help to fill in this gap, we have studied the development of $F$. arundinacea plants with different basic amounts of nuclear DNA at the cellular and organismal level. The results obtained are reported in this paper.

\section{Materials and methods}

\section{Plants}

Seeds (caryopses) collected from 30 natural populations of hexaploid $F$. arundinacea with known genome size (Ceccarelli et al., 1992) were allowed to germinate at $10^{\circ} \mathrm{C}, 20^{\circ} \mathrm{C}$ or $30^{\circ} \mathrm{C}$, with a photoperiod of $12 \mathrm{~h}$ in the light $(3000 \mathrm{~lx})$ and $12 \mathrm{~h}$ in the dark. Seeds were set on filter paper moistened with distilled water, and placed in Petri dishes or arranged in ranks which were in contact with distilled water. The plantlets were then pricked out in Jiffy pots into mould which had been sterilized by autoclaving, and were grown in the same conditions as above.

\section{Cytology}

Seedlings obtained by germinating seeds at $20^{\circ} \mathrm{C}$ were treated for $30 \mathrm{~min}$ at the same temperature with an aqueous solution of ${ }^{3} \mathrm{H}$-thymidine (The Radiochemical Centre; specific activity $\left.6.7 \mathrm{Ci} \mathrm{mmol}^{-1}\right)$ at a concentration of $5 \mu \mathrm{Ci} \mathrm{ml}^{-1}$ and, after a thorough washing, they were recovered in water. Seminal roots collected after 2-30 h of recovery were fixed in 3:1 ethanol:acetic acid $(\mathrm{v} / \mathrm{v})$ and Feulgen-stained after hydrolysis in $\mathrm{N} \mathrm{HCl}$ at $60^{\circ} \mathrm{C}$ for $8 \mathrm{~min}$. Root tips were then squashed in a drop of 45 per cent acetic acid under a coverslip after treatment with a 5 per cent aqueous solution of pectinase (Sigma) for $15 \mathrm{~min}$ at $37^{\circ} \mathrm{C}$. The coverslips were then removed by the solid $\mathrm{CO}_{2}$ method and the preparations were covered with Ilford $\mathrm{L}_{4}$ emulsion, developed after 7 days of exposure, dehydrated and mounted in DPX (BDH Chemicals). The percentage of labelled mitoses after different recovery durations was determined, and the duration of the mitotic cycle and its phases was calculated according to Quastler \& Sherman (1959) and Wimber (1960).
First foliage leaves at the end of their growth were collected from plants grown at $20^{\circ} \mathrm{C}$, and their adaxial epidermis was peeled off after a 30 min treatment with 5 per cent pectinase as above. The leaf peels were then placed on gelatin-coated slides with their external faces in contact with gelatin, thus ensuring easy penetration of the dye into the epidermal cells, and stained with Delafield's haematoxylin (Merck). The length and width of cells belonging to different lineages were measured using a nonium-equipped ocular micrometer.

\section{Plant development}

Seed dormancy was tested by attempting to germinate seeds every week after harvesting. The germination power was evaluated according to Davet-Fresia \& Valdeyron (1966), 42 days after seed harvesting.

The length of seminal roots was measured daily and that of the first foliage leaves every 2 days. The following quantitative characters of plants at anthesis grown in the open air in the experimental field were determined: (i) length and maximum width of a basal leaf (the third to the last one of a sterile shoot); (ii) height (from soil to the apex of the panicle) of the highest culm, on which all the characters below were observed; (iii) length and maximum width of the flag leaf; (iv) length of the panicle from the basal branch to the apex; (v) number of branches on the basal node of the panicle; (vi) length of the longest basal branch; (vii) number of spikelets on the longest and the shortest basal branch; (viii) length of a spikelet (the second from the base of the longest branch); (ix) number of flowers on the same spikelet; and $(x)$ length of the lemma awn.

\section{Results}

\section{Cytology}

The duration of the mitotic cycle and its phases were determined in seedlings obtained from seeds collected at Cesenatico (district of Forli, Northern Italy) and Baronissi (district of Salerno, Southern Italy), which differ largely in genome size, since they have C-values of $6.05 \mathrm{pg}$ and $8.28 \mathrm{pg}$, respectively (Ceccarelli et al., 1992). Figure 1 gives the results obtained by feeding seedlings with ${ }^{3} \mathrm{H}$-thymidine and then scoring labelled metaphases in the root meristems after different durations of recovery in water. These results, together with those also obtained by scoring labelled prophases between 2 and $4 \mathrm{~h}$ of recovery, and by calculating the relative ratios of cells in different karyokinetic phases (data not shown), are tabulated in Table 1.

The mitotic cycle time is $3 \mathrm{~h}$ longer in the seedlings with a larger genome than in those with a smaller 
genome, and a longer duration of the $G_{1}$ phase in the plants with a larger genome mostly accounts for this difference. By contrast, significant differences cannot be observed when comparing the mitotic indices in the root or leaf meristems in the two groups of seedlings (Table 1). These results indicate that, while cell proliferation is faster in plants with a lower basic amount of DNA, the genome size does not affect the proportion of cells entering mitosis.

Likewise, in $F$. arundinacea, quantitative changes in nuclear DNA content do not seem to determine differences in cell growth. Indeed, cells of different lineages in the epidermis of leaves belonging to plants obtained from seeds collected at Baronissi and Cesenatico have comparable sizes (data not shown).

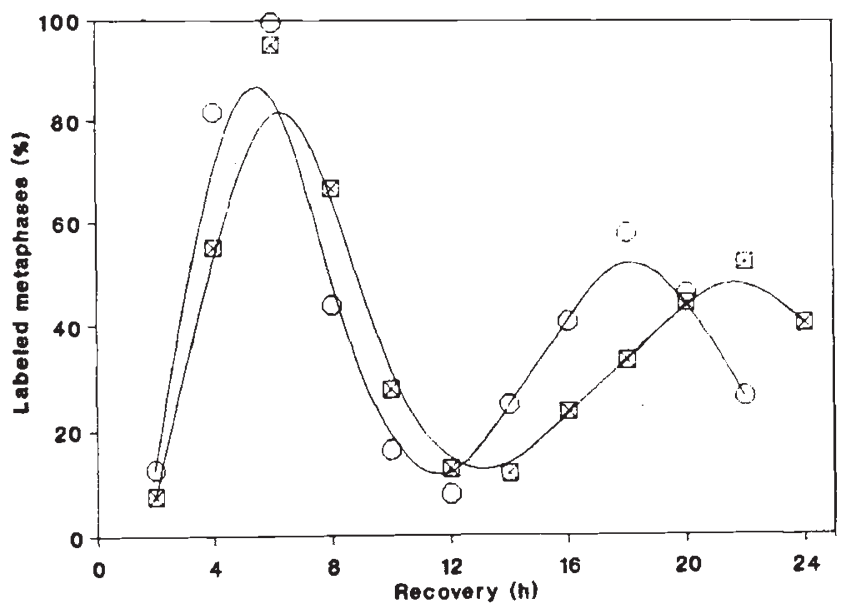

Fig. 1 Percentages of metaphases labelled after a feeding with ${ }^{3} \mathrm{H}$-thymidine lasting $30 \mathrm{~min}$, followed by different recovery times in water. Each point is the mean of the values obtained by analysing the root meristems of five seedlings obtained from seeds collected from two populations differing in genome size: at Cesenatico (O), or Baronissi ( $)$ stations. 50 metaphases were scored in each seedling.

\section{Plant development}

No significant difference was observed between 30 populations as far as seed dormancy is concerned (data not shown). In all the populations nearly all the seeds were able to germinate within $48 \mathrm{~h}$ after 42 days from harvesting. However, the data given in Fig. 2 show that a significant correlation exists between the genome size of each population and the germination power of their seeds: the larger the genome size, the lower the germination power.

In Figs 3 and 4, the growth of the seminal root and the first foliage leaf in plantlets obtained from seeds collected at Cesenatico and Baronissi are compared. As expected from the above-reported cytological results, the growth of both organs is faster in the plantlets obtained from seeds collected at Cesenatico than in those from seeds collected at Baronissi, particularly during their early development. Comparable trends are observed at all the three temperatures used $\left(10^{\circ} \mathrm{C}\right.$, $20^{\circ} \mathrm{C}$ or $30^{\circ} \mathrm{C}$ ), even if, with the root, apparent quantitative differences in the response to different temperatures can be observed (Fig. 3). The existence of a correlation between genome size and early plant development was proven by studying the growth of the seminal root and the first foliage leaf in all 30 populations. Figures 5 and 6 show that their DNA C-values are correlated negatively with the lengths of both organs 10 days after seed germination.

The results given in Figs 7 and 8 were obtained by studying mature plants. It can be seen from Fig. 7 that a significant correlation exists between the genome size of the populations and the height of the highest culm in plants at anthesis. However, in this case, the correlation is positive. Also, other quantitative characteristics of flowering plants, such as the number of flowers per spikelet or the length of the lemma awn, correlate positively with their DNA C-values (data not shown). Figure 8 shows that a significant correlation (also posi-

Table 1 Length of the mitotic cycle and its phases (as determined on the basis of the results given in Fig. 1) and mitotic index in the root and leaf meristem, in seedlings obtained from seeds collected in two populations differing in genome size

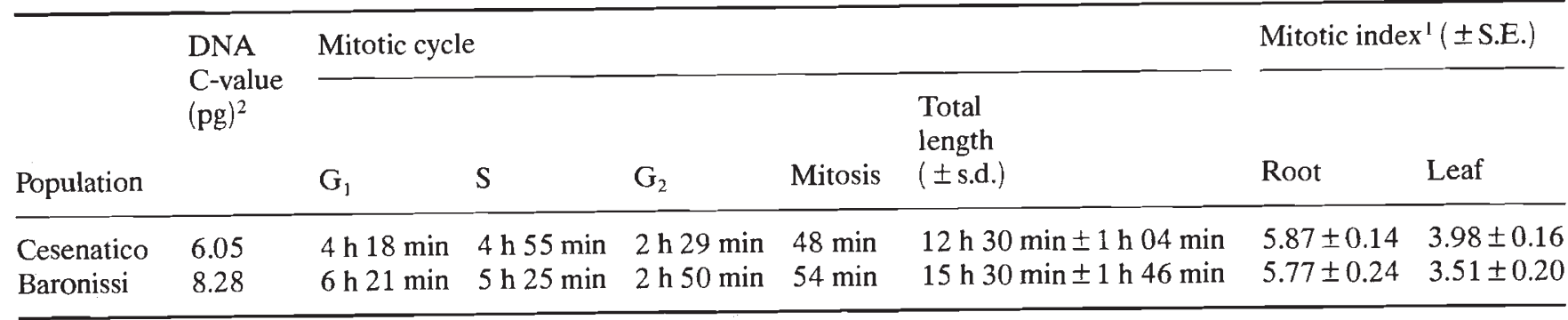

${ }^{1}$ In order to calculate the mitotic indices, 3000 cells were scored in each meristem of five seedlings per population.

${ }^{2}$ Data from Ceccarelli et al., 1992. 


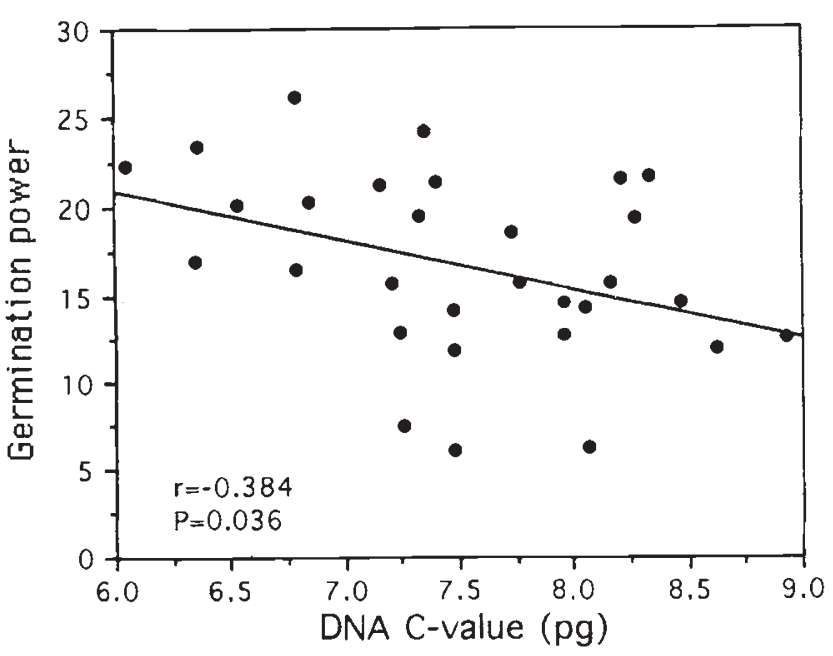

Fig. 2 Correlation between the germination power of the seeds and the genome size in 30 populations. 60 seeds per population were germinated. For this correlation and those given in Figs 5-8, DNA C-values were taken from Ceccarelli et al. (1992).

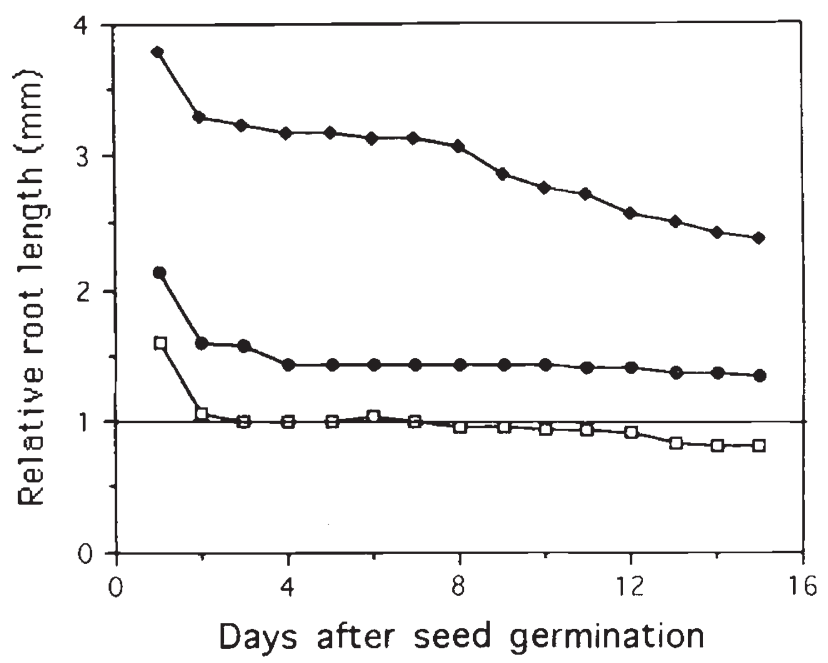

Fig. 3 Growth of the seminal root at $10^{\circ} \mathrm{C}(\square), 20^{\circ} \mathrm{C}(\bullet)$ or $30^{\circ} \mathrm{C}(\bullet)$ in seedlings obtained from seeds collected at Cesenatico and Baronissi. The values were normalized (Baronissi $=1$ ) to facilitate the comparison. 60 seedlings for each population were studied.

tive) exists between the genome size of the populations and the flowering time.

\section{Discussion}

Our results show that changes in the basic amount of nuclear DNA within hexaploid $F$. arundinacea influence plant phenotype by affecting seed germination and growth rates during early development, as well as

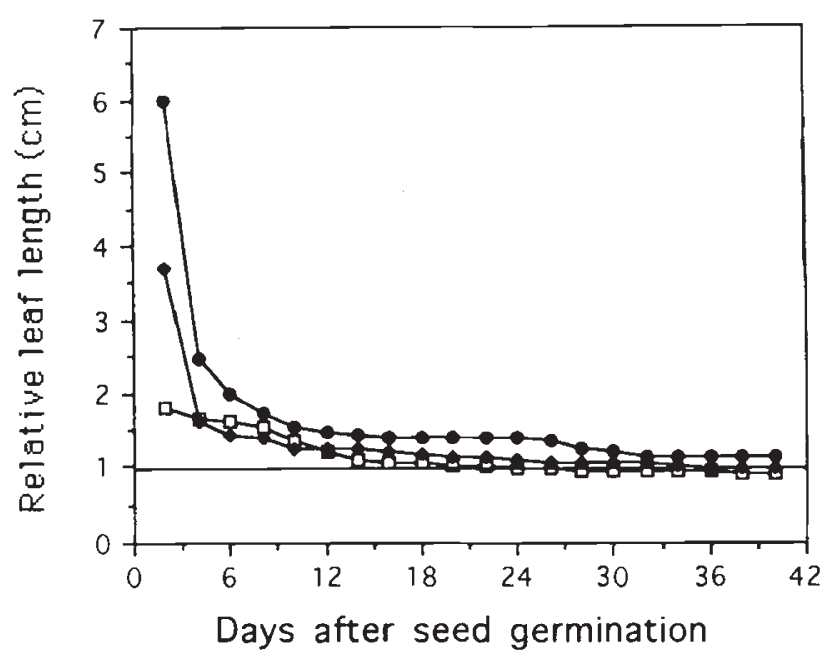

Fig. 4 Growth of the first foliage leaf at $10^{\circ} \mathrm{C}(\square), 20^{\circ} \mathrm{C}(\bullet)$ or $30^{\circ} \mathrm{C}(\bullet)$ in seedlings obtained from seeds collected at Cesenatico and Baronissi. The values were normalized (Baronissi = 1) to facilitate the comparison. 60 seedlings for each population were studied.

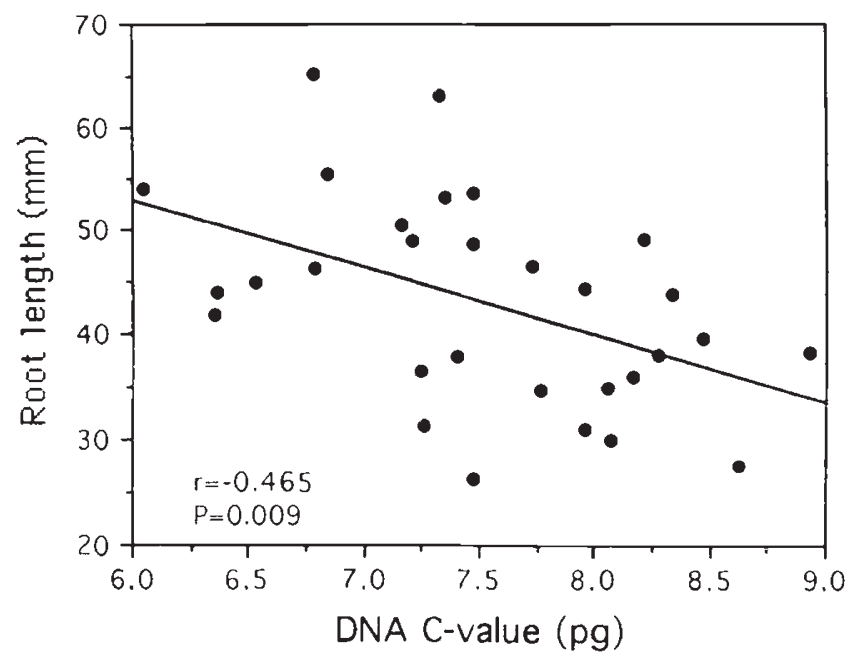

Fig. 5 Correlation between the mean length of seminal roots after 10 days from seed germination and the genome size in 30 populations. 60 seedlings per population were studied.

certain quantitative characters of mature plants and the generation time. The existence of significant correlations between genome size and plant characters found by studying a number of populations (Figs 2 and 5-8) clearly excludes that genetic diversity of another kind between them may be responsible for the observed changes in development. Thus, our findings may be added to a few others in the literature providing convincing evidence that intraspecific variation of the DNA C-value actually has biological consequences in that it is able to alter certain developmental characters 


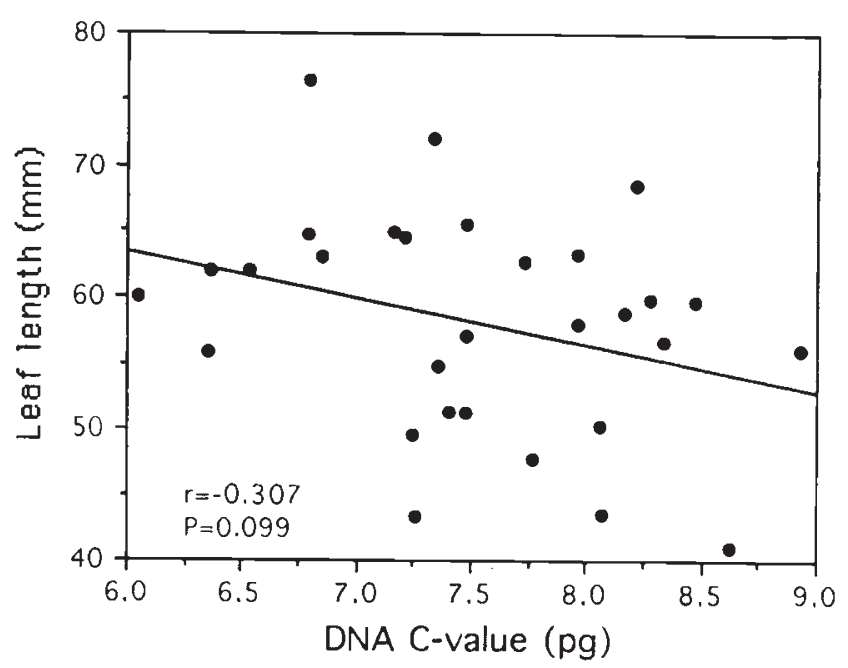

Fig. 6 Correlation between the mean length of the first foliage leaves after 10 days from seed germination and the genome size in 30 populations. 60 seedlings per population were studied.

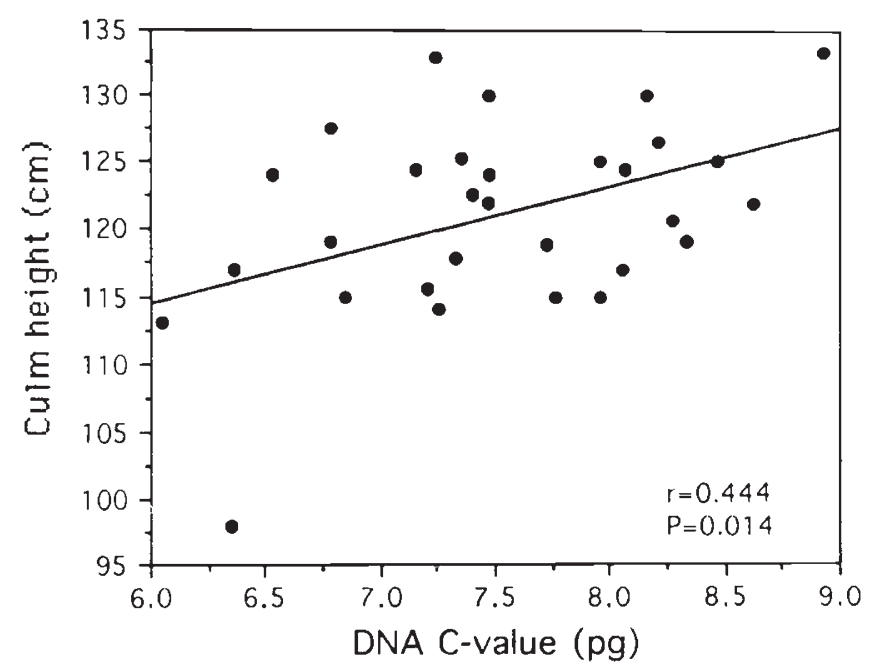

Fig. 7 Correlation between the mean height of the highest culm in plants at anthesis and the genome size in 30 populations. 60 plants per population were measured.

of plants (reviewed by Cavallini \& Natali, 1991; Cavallini et al., 1993; Natali et al., 1993).

We suggest that these changes in development are produced through nucleotypic (Bennett, 1972) effects. By comparing the nuclear DNA amounts of different species with their developmental features, evidence has accumulated that DNA mass and volume per se can influence phenotypic characters (reviewed by Bennett, 1985; 1987; Price, 1988). Moreover, such developmental parameters as mitotic cycle duration or generation time may be affected by different kinds of quantitative variation in the nuclear DNA, such as the

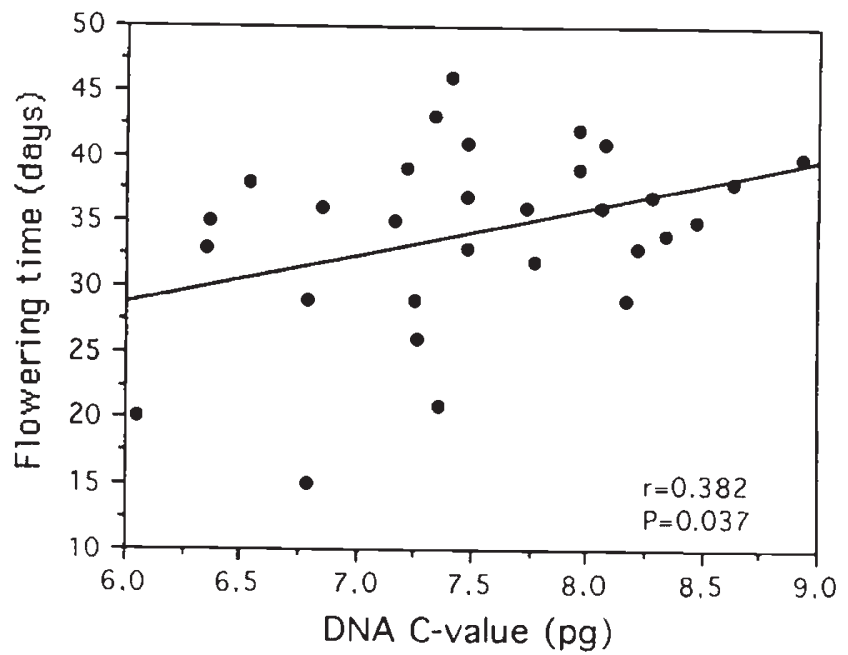

Fig. 8 Correlation between the flowering time and the genome size in 30 populations. 60 plants per population were studied.

addition of supernumerary chromosomes (Jones \&. Rees, 1982). The DNA content differs by up to 32.3 per cent between the populations of $F$. arundinacea studied (Ceccarelli et al., 1992), and differences of 5-10 per cent have been indicated as enough to determine changes in nucleotype expression (Price, 1988).

When the results given in this paper are compared with those obtained from similar studies on other species, it appears that certain phenotypic features at both the cellular and organismal level are affected in different ways by the intraspecific variation in the amount of nuclear DNA - probably on account of the genetic diversity occurring between species. For example, genome size correlates positively with cell enlargement in Helianthus annuus and Pisum sativum, while no such correlation can be found in $F$. arundinacea. The correlation between the DNA C-value and plant growth rate is negative in $F$. arundinacea (Figs 5 and 6 ), while it is positive in $P$. sativum and non-existent in $H$. annuus. The generation time is correlated positively with the genome size in $F$. arundinacea (Fig. 8) and $H$. annuus, while no such correlation exists in $P$. sativum (cf. data presented here with that of Natali et al., 1993 and Cavallini et al., 1993). Hence, it appears that the effects on development of intraspecific variations in genome size may differ according to species, leading to different adaptive strategies in different plants.

As far as $F$. arundinacea is concerned, the DNA C-values of its populations, which correlate positively with the mean temperature during the year and with that of the coldest month at the stations (Ceccarelli et al., 1992; see Introduction), also correlate negatively with the germination power of the seeds (Fig. 2) and 
the growth rate, particularly during early plant development (Figs 5 and 6) and positively with the generation time (Fig. 8). Therefore, the variation in the basic amount of nuclear DNA within this species may be thought of as having a role in improving the fitness of plants growing in environments differing in climatic factors such as temperature.

In connection with this, it seems worth noting that the germination power of the seeds and the growth of roots and leaves, which are developmental events taking place during winter and early spring, are correlated negatively with the genome size (Figs 5 and 6), while the height of culms and other quantitative characters of plant organs developing later in the warmer season, are positively correlated with the genome size (Fig. 7). Thus, the variation in the basic amount of nuclear DNA within $F$. arundinacea may represent a factor in the evolution of this species, which is distributed in a wide geographical area (MarkgrafDannenberg, 1980). Correlations between low DNA contents and adaptation to stressful environments (low temperatures) have been suggested by studying the $\mathrm{C}$-value variation within other species (e.g. Microseris bigelovii; Price et al., 1981). By contrast, when considering differences in genome size between species, the capacity to grow at lower temperatures seems to be associated with the possession of a large genome (cf. Moore, 1985).

Finally, it may be worth considering that the observed correlations between genome size and developmental characters of plants, together with that already observed between genome size and a climatic factor (Ceccarelli et al., 1992), may be of some interest in the genetic improvement of $F$. arundinacea, which represents an important herbage crop in temperate regions.

\section{Acknowledgements}

Research supported by National Research Council, Italy, Special Project RAISA, Sub-project no. 2, Paper no. 1091.

\section{References}

BASSI, P. 1990. Quantitative variations of nuclear DNA during plant development: a critical analysis. Biol. Rev., 65, 185-225.

BENNETT, M. D. 1972. Nuclear DNA content and minimum generation time in herbaceous plants. Proc. R. Soc. London, Ser. B, 181, 109-135.

BENNETT, M. D. 1985. Intraspecific variation in DNA amount and the nucleotypic dimension in plant genetics. In: Freel- ing, M. (ed.) Plant Genetics, A. R. Liss, New York, pp. 283-302.

BENNETT, M. D. 1987. Variation in genomic form in plants and its ecological implications. New Phytol., 106, 177-200.

CAVALLINI, A. AND NATALI, L. 1991. Intraspecific variation of nuclear DNA content in plant species. Caryologia, 44, 93-107.

CAVAllini, A., Natali, L., Cionini, G. AND Gennai, D. 1993. Nuclear DNA variability within Pisum sativum (Leguminosae): nucleotypic effects on plant growth. Heredity, $\mathbf{7 0}$, 561-565.

CECCARELLI, M., FALISTOCCO, E. AND CIONINI, P. G. 1992. Variation of genome size and organization within hexaploid Festuca arundinacea. Theor. Appl. Genet., 83, 273-278.

CENCI, C. A., CECCARELli, M., PASQUALINI, S., FALCINELli, M. AND CIONINI, P. G. 1990. Festuca arundinacea Schreber (Gramin$e a e)$ in Italy: morphological, anatomical, karyological and biochemical analyses. Webbia, 44, 255-270.

CIONINI, P. G. 1989. Nuclear DNA changes during plant development. Giorn. Bot. Ital., 123, 111-121.

CULLIS, C. A. 1990. DNA rearrangements in response to environmental stress. Adv. Genet., 28, 73-97.

DAVET-FRESIA, M. AND VALDEYRON, G. 1966. L'umidité des glands de Quercus ilex L.: facteur essential de leur conservation. Naturalia Monspell., Sér. Bot., 17,97-101.

DoolitTle, w. F. AND SAPIENZA, C. 1980. Selfish genes, the phenotype paradigm and genome evolution. Nature, 284, 601-603.

JONES, R. N. AND REES, H. 1982. B chromosomes. Academic Press, London.

MARKGRAF-DANnEnBerg, 1. 1980. Festuca $L$. In: Tutin, T. G. et al. (eds), Flora Europaea, vol. 5, pp. 125-133.

MOORE, P. D. 1985. Nuclear DNA content as a guide to plant growth rate. Nature, 318, 412-413.

NAGL, w. 1990. Gene amplification and related events. In: Bajaj, Y. P. S. (ed.) Biotechnology in Agriculture and Forestry, vol. 11, Springer, Berlin, Heidelberg, New York, pp. 153-201.

NATALI, L., CAVALliNI, A., CIONINI, G., SASSOLI, O., CIONINI, P. G. AND DURANTE, M. 1993. Nuclear DNA changes within Helianthus annuus $\mathrm{L} .:$ changes within single progenies and their relationships with plant development. Theor. Appl. Genet., $\mathbf{8 5}, 506-512$.

ORGEL, L. E. AND CRICK, F. H. C. 1980. Selfish DNA: the ultimate parasite. Nature, 284, 604-607.

PRICE, H. J., CHAMBERS, K. L. AND BaChmanN, K. 1981. Geographic and ecological distribution of genomic DNA content variation in Microseris douglasii (Asteraceae). Bot. Gaz., 142, 415-428.

PRICE, H. J. 1988. DNA content variation among higher plants. Am. Missouri Bot. Gard., 75, 1248-1257.

QUASTLER, H. AND SHERMAN, F. G. 1959. Cell population kinetics in the intestinal epithelium of the mouse. Exp. Cell Res., 17, 420-438.

WIMBER, D. E. 1960. Duration of the nuclear cycle in Tradescantia paludosa root tips as measured with ${ }^{3} \mathrm{H}$-thymidine. Am. J. Bot., 47, 828-834. 